\title{
An Integrative Review of Causes, Manifestations and Evaluation of Cognitive Fatigue among Persons with Multiple Sclerosis
}

\author{
Lana M. Pasek ${ }^{1 *}$ \\ ${ }^{1}$ University at Buffalo, The State University of New York, USA \\ *Corresponding Author - Lana M. Pasek, University at Buffalo, The State University of New York, USA. \\ Email: pasek@buffalo.edu \\ DOI: https://dx.doi.org/10.47988/janany.53233323.1.1
}

\begin{abstract}
Background: Fatigue is the most distinguishing symptom for patients with Multiple Sclerosis (MS) and for some of these patients it can be quite disabling. Studies exploring MS-related fatigue have differentiated this into various dimensions: motor, cognitive, physical, psychosocial, performance, and subjective. It is the cognitive dimension that can have serious consequences such as loss of vocation, independence, and possibly, more relapses or worsening of the disease.

Objective: The aims of this integrative review were to explore the advances in understanding cognitive fatigue in MS, as well as its causes and manifestations, and to identify the objective methodologies that best measure cognitive fatigue in MS.

Methodology: An integrative review of the scientific literature was performed using methods and criteria following the PRISMA-P2015 guidelines for data extraction. The studies were critically appraised using the Rapid Critical Appraisal and the qualitative study method of Constant Comparison.

Results: Twenty-three studies (2010-2019) were identified from the United States and other countries. The majority of articles were published within the last three years. Evaluation of outcomes from these studies was conducted through self-reporting. Cognitive fatigue may result in more relapses among those with relapsing and remitting MS and from those with secondary progressive MS. Cognitive fatigue and physical fatigue should be considered distinct domains.

Conclusion and Recommendations: An increasing number of studies focused on cognitive fatigue, however, there is no standard definition or conceptual framework available to understand this phenomenon. Various methodologies were identified to evaluate cognitive fatigue. Additionally, there should be a valid, reliable, and readily available instrument for use in the clinical setting.
\end{abstract}

Keywords: Multiple Sclerosis, Cognitive Fatigue, Fatigue, Integrative Review

Funding: The author did not receive any funding from the public, commercial, or not-for-profit sectors.

Conflict of Interest: The author declare no actual or potential conflict of interest. 


\section{An Integrative Review of Causes, Manifestations and Evaluation of Cognitive Fatigue among Persons with Multiple Sclerosis}

Multiple Sclerosis (MS) is a disease that is life-long, chronic and affects motor and cognitive functions with characteristic progressive multifocal deficits affecting the central nervous system (Marshall \& Mayer, 2007). This disease is a prevalent cause of disability for adults between $30-50$ years of age, and affecting females close to three times more frequently than males (Halper \& Harris, 2017; Marshall \& Mayer, 2007). It is also unclear why populations in the United States north of the 37th parallel of the Earth's equatorial plane have a higher risk of developing MS (Halper \& Harris, 2017).

\section{Pathophysiology}

The etiology of MS is unknown, however, it is considered an autoimmune disease because of the presence of inflammation within damaged myelin nerve fibers (Marshall \& Mayer, 2007). Defining characteristics of MS are distinct - firm plaques occurring in the brain white matter and spinal cord, changes in important neurotransmitter concentrations, and brain atrophy as seen on magnetic resonance imaging (MRI) (Marshall \& Mayer, 2007). In a large multi-site study of MS patients with fatigue and low disability scores, researchers concluded from MRI scan results that independent of disability, white and grey matter brain atrophy is a risk factor for fatigue in MS (Tedeschi et al., 2007).

\section{Fatigue}

Fatigue is the most common disabling symptom in MS affecting over $80 \%$ of persons with MS. For many it is the most challenging to manage on a daily basis, and $40 \%$ of those with MS consider it their most disabling symptom resulting in decreased quality of life and a significant reason for forfeiture of a vocation or employment (Blikman et al., 2018; Braley \& Chervin, 2010; Halper \& Harris, 2017; Marshall \& Mayer, 2007; Morrison \& Stuifbergen et al., 2016; Tedeschi et al., 2007; Touzet, 2017; Vaughn, et al., 2018; Walker et al., 2019). The purpose of this integrative review was to understand new developments about the dimensions of cognitive fatigue, especially its causes and evaluations, in order to detect its manifestations and intervene accordingly.

\section{Defining Fatigue}

Fatigue in the general population is described as an overpowering sense of exhaustion resulting in less reserves for physical and mental work at a person's usual level of functioning (Given \& Sherwood, 2006). Researchers have regarded general fatigue as an individual subjective phenomenon that is described as a shortage of energy after engaging in physical or mental activities and is usually measured by self-report (Walker et al., 2019). MS fatigue has been defined by the Multiple Sclerosis Council for Clinical Practice Guidelines (Blikman et al., 2018) as being associated with a person's physical behavior, daily physical functioning, and activities accomplished in daily life. However, the various dimensions of fatigue in MS are not yet well defined.

\section{Dimensions of Fatigue}

Throughout the years the concept of fatigue evolved to be twodimensional: motor and cognitive (Claros-Salinas et al., 2012). Recently, however, other dimensions have gone through some iterations, e.g., the dimensions of fatigue changed from motor to physical and included a psychosocial element (Morrison \& Stuifbergen, 2016). Aldughmi et al. (2017) described the various dimensions as perceived physical, cognitive and the addition of performance fatigue. Blikman et al. (2018) described four components of fatigue as physical, cognitive, psychosocial and added a subjective dimension. Blikman et al. (2018) derived the four dimensions from the subscales of two multi-dimensional fatigue self-report questionnaires: Checklist Individual Strength (CIS20r) and Modified Fatigue Impact Scale (MFIS).

\section{Cognitive Fatigue}

Cognitive fatigue is included within the dimensions of MS fatigue. However, Berard et al. (2018) stated that there is no unanimous definition for cognitive fatigue. The authors defined it as the "inability to maintain optimal task performance throughout a sustained attention task" (Berard et al., 2018, p. 55). Moreover, cognitive fatigue is a collection of multiple deficits resulting in decreased functions of alertness, focused attention and reduced mental processing of information (Berard et al., 2018).

Hanken et al. (2015) concluded that MS fatigue maybe the feeling related to the inflammation occurring in the nerves that is evident in the person's behavior if they need to rely on distinct cognitive processes. The feeling that Hanken et al. (2015) described in MS fatigue distracts the person's attention away from the cognitive processes of the moment. This is similar to feeling pain that distracts a person's attention. The researchers further explained that the feeling of fatigue with the reduced behavioral outcomes may be caused by brain atrophy that occurs in MS or the neurochemical imbalances affecting alertness and vigilance (Hanken et al., 2015).

\section{Objective Measures}

As research evolved related to MS, questionnaires were developed for self-reporting with attempts to quantify fatigue and evaluate its impact on day to day functioning for persons with MS (Walker et al., 2019). Walker et al. (2019) listed scales that were developed between 1989 and 2012, e.g., Fatigue Severity Scale, Fatigue Impact Scale, Neurological Fatigue Index, Mental Fatigue Scale, Fatigue Assessment Scale, Multidimensional Fatigue Inventory, and the Fatigue Scale for Motor and Cognitive Functions. Objective measurement leads to quantification of cognitive fatigue, thereby, positively impacting disability benefits for people afflicted with MS related cognitive fatigue (Walker et al., 2019). Harrison et al. (2017) summarized various measures of cognitive fatigue in MS. They agreed that self-reporting is important among people with MS because it is their perception of the fatigue impact on their lives. Harrison et al. (2017) 
recommended that these measures be further explored and improved.

Berard et al. (2018) suggested that the current state of the science for measuring MS related cognitive fatigue objectively is the Paced Auditory Serial Addition Test (PASAT) as a sensitive and valid tool. The PASAT compares initial task performance with later performances. People with MS are expected to have decreased performances as the task is measured over time because it becomes more difficult to quickly process necessary information for task completion (Berard et al., 2018). Touzet (2017) described direct methodologies to objectively identify cognitive fatigue with functional magnetic resonance imaging (fMRI), whereby patients with MS engage in cognitive tasks during fMRI scans. The MRI scans resulted in altered cerebral activations that were not seen among healthy control cohorts. Touzet (2017) also noted that diffuse tensor imaging (DTI) scans demonstrated a pattern of cerebral activities for patients who had self-reporting of increased fatigue on the Fatigue Severity Scale.

\section{Methods}

The adherence to ethical considerations for this integrative review was determined by previously conducted experimental, quasi-experimental, and non-experimental studies whose authors received Institutional Review Board approval. The methods and criteria for study followed the PRISMA-P2015 (Preferred Reporting Items for Systematic Reviews and Meta-Analysis) checklist and guideline recommendations of components such as population, intervention, comparison, and outcome (PICO) (Moher et al., 2015) (Table 1).
Table 1

Problem, Intervention, Comparison and Outcome (PICO) Strategy ${ }^{a}$

\begin{tabular}{|c|c|}
\hline Element & Description \\
\hline Patient & $\begin{array}{l}\text { Adults with all types and subtypes of multiple } \\
\text { sclerosis (MS) }\end{array}$ \\
\hline Problem & $\begin{array}{l}\text { Fatigue is not a well understood symptom. } \\
\text { There is general fatigue related to daily living } \\
\text { factors such as inadequate sleep or depression. } \\
\text { There is also disease related fatigue of which } \\
\text { in MS it is a common symptom. Evidence } \\
\text { has been increasing that the subjective feeling } \\
\text { of fatigue in MS has distinct components, } \\
\text { physical and cognitive } \text {. Research around the }_{\text {concepts of cognitive fatigue and cognitive }} \\
\text { fatigability are evolving and needs more } \\
\text { inspection as these may impact quality of life } \\
\text { and treatment approaches in MS.c }\end{array}$ \\
\hline Intervention & $\begin{array}{l}\text { Observe/Screen for the advancement in } \\
\text { knowledge of the causes, evaluation and } \\
\text { manifestations of cognitive fatigue in patients } \\
\text { with MS }\end{array}$ \\
\hline Comparison & $\begin{array}{l}\text { Those patients who develop other identified } \\
\text { dimensions of fatigue and cognitive } \\
\text { impairment. }\end{array}$ \\
\hline Outcome & $\begin{array}{l}\text { Updated developments in the cause, evaluation } \\
\text { and manifestations of cognitive fatigue. }\end{array}$ \\
\hline $\begin{array}{l}\text { Inclusion } \\
\text { Criteria }\end{array}$ & $\begin{array}{l}\text { Adults, all genders identified and not } \\
\text { identified, ages } 18-89 \text { years, who have all } \\
\text { types and subtypes of MS from any world } \\
\text { population. Studies: Descriptive, reports, } \\
\text { mixed-methods, longitudinal, experimental } \\
\text { and quasi-experimental. }\end{array}$ \\
\hline $\begin{array}{l}\text { Exclusion } \\
\text { Criteria }\end{array}$ & $\begin{array}{l}\text { Less than } 18 \text { years of age or older than } 89 \\
\text { years old. Studies more than } 15 \text { years old } \\
\text { ( } 2003 \text { and older). Foreign language. }\end{array}$ \\
\hline Question & $\begin{array}{l}\text { What has been discovered in the last } 15 \\
\text { years concerning the causes, evaluations and } \\
\text { manifestations of cognitive fatigue? }\end{array}$ \\
\hline $\begin{array}{l}\text { Type of } \\
\text { Problem }\end{array}$ & Prognostic value \\
\hline Type of Study & Integrative Review \\
\hline $\begin{array}{l}\text { Main } \\
\text { Topics and } \\
\text { Alternative } \\
\text { Terms }\end{array}$ & $\begin{array}{l}\text { Cognitive fatigue, fatigue, physical fatigue, } \\
\text { relapsing/remitting multiple sclerosis, } \\
\text { progressive symptoms, multiple sclerosis }\end{array}$ \\
\hline Plan to Search & $\begin{array}{l}\text { Databases: CINAHL, PubMed, Web of } \\
\text { Science, Medline via Web of Science, Science } \\
\text { Direct. Handsearching through electronic } \\
\text { libraries of University at Buffalo The State } \\
\text { University of New York }\end{array}$ \\
\hline
\end{tabular}

${ }^{\mathrm{a}}$ Moher et al., $2015^{\mathrm{b}}$ Gullo et al., $2019{ }^{\mathrm{c}}$ Walker et al., 2019 
The integrative literature review was conducted with the expert assistance of the professional medical librarian associated from the university's school of nursing. The search strategy is shown in Figure 1 in a diagram format using the PRISMA guidelines (Moher et al., 2009).

\section{Figure 1}

\section{PRISMA Flow of Information Diagram}

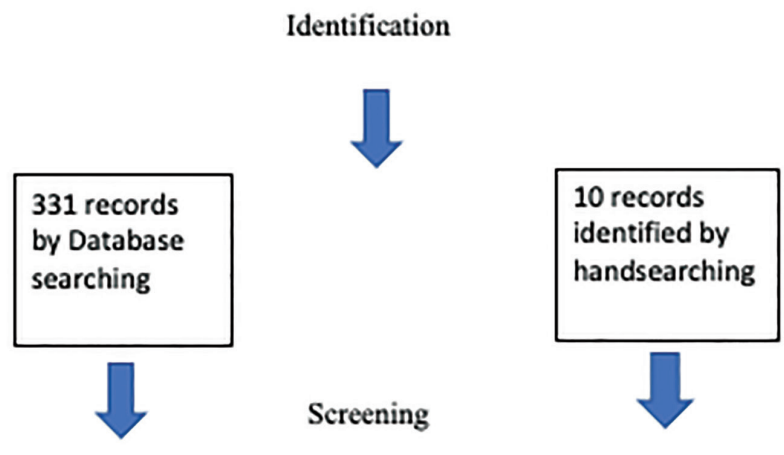

143 duplicates removed

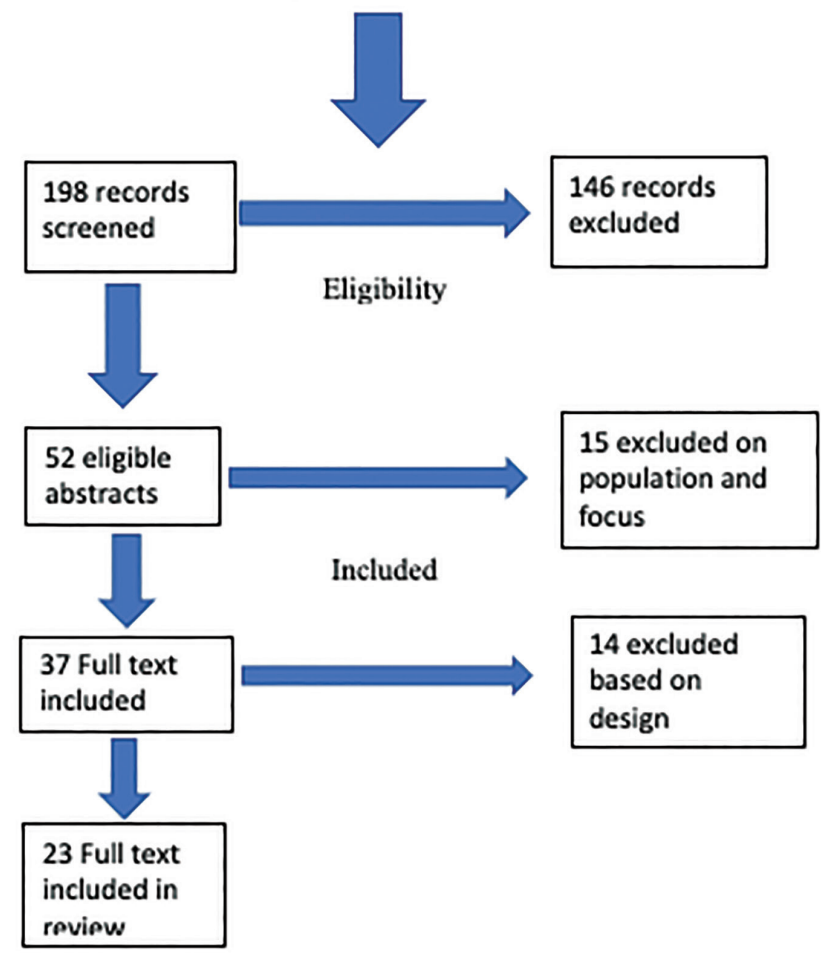

A literature search was performed using CINAHL, PubMed, Web of Science, Medline via Web of Science, and Science Direct databases. Patients with MS that showed a pattern of relapsingremitting MS (RRMS) were included in the search because 85\% of patients have this feature (Marshall \& Mayer, 2007). Relevant articles were searched using keywords and Boolean operators OR and AND in various combinations as shown in Table 2. The search strategy identified 331 potential articles. Hand search of systematic reviews (Walker et al., 2019) added nine titles and an additional study by Vaughn et al. (2018). The author of this integrative review attended a lecture presentation given by Vaughn and found the article written by her and her colleagues relevant to this review.

Table 2

Search Concepts and Boolean Operators

\begin{tabular}{|c|c|c|c|c|}
\hline Concept & Boolean & Concept & Boolean & Concept \\
\hline $\begin{array}{l}\text { Cognitive } \\
\text { Fatigue }\end{array}$ & OR & $\begin{array}{l}\text { Physical } \\
\text { Fatigue }\end{array}$ & AND & $\begin{array}{l}\text { Relapsing } \\
\text { Remitting } \\
\text { Multiple } \\
\text { Sclerosis }\end{array}$ \\
\hline $\begin{array}{l}\text { Cognitive } \\
\text { Fatigue }\end{array}$ & AND & $\begin{array}{l}\text { Physical } \\
\text { Fatigue }\end{array}$ & OR & $\begin{array}{l}\text { Relapsing } \\
\text { Remitting } \\
\text { Multiple } \\
\text { Sclerosis }\end{array}$ \\
\hline $\begin{array}{l}\text { Relapsing } \\
\text { Remitting } \\
\text { Multiple }\end{array}$ & AND & $\begin{array}{l}\text { Progressive } \\
\text { Symptoms }\end{array}$ & & \\
\hline $\begin{array}{l}\text { Physical } \\
\text { Fatigue }\end{array}$ & AND & $\begin{array}{l}\text { Relapsing } \\
\text { Remitting } \\
\text { Multiple } \\
\text { Sclerosis }\end{array}$ & & \\
\hline Physical & AND & $\begin{array}{l}\text { Cognitive } \\
\text { Fatigue in } \\
\text { Multiple } \\
\text { Sclerosis }\end{array}$ & & \\
\hline \multicolumn{5}{|c|}{$\begin{array}{l}\text { Relapsing Remitting } \\
\text { Multiple Sclerosis }\end{array}$} \\
\hline Cognitive & atigue & & & \\
\hline
\end{tabular}

The ten hand searched studies accounted for a total of 341 research identified. After removal of duplicates and foreign language articles, 198 studies were left to review. Titles and abstracts of the remaining articles were screened for inclusion. This yielded fifty-two eligible abstracts and excluded 15 based on the set criteria. The remaining thirty-seven articles were filtered to only those that are full text. Fourteen publications were excluded, leaving 23 studies for the final analysis (Table 3 at end of this article).

\section{Quality Review}

The 23 research studies were reviewed using a Rapid Critical Appraisal method to evaluate the validity of the instruments used to measure the outcomes (Mazurek Melnyk et al., 2010). The results were reliable and most of the studies were descriptive cohort designs. Lastly, those included needed to be inclusive of patients with various types of MS (relapsing remitting, primary and secondary progressive) with a focus on fatigue and cognitive fatigue.

The studies were further evaluated using the qualitative study method of Constant Comparison (Charmaz, 2012) and the extracted data were compared and subsequently categorized by theme, type of fatigue, type of MS, participant number and ages, 
study design, presence of a theoretical framework, and research outcomes (Table 3 ). Finally, the 23 studies were organized, filed and stored in a software tool for managing bibliographies.

\section{Study Descriptive Statistics}

Of the 23 studies, seven originated in the United States and the majority $(n=16)$ were international studies. Those that came from other countries included Germany $(n=5)$ and Canada $(n=3)$. The research studies spanned over nine years from 2010 to 2019. Fifteen of the studies $(65 \%)$ were published within the last three years: $2019(n=6), 2018(n=6)$, and $2017(n=3)$. The majority of the researchers focused on the manifestation of fatigue $(52 \%$, $\mathrm{n}=12)$ while there were five studies $(22 \%)$ that explored its causes.

\section{Type of Fatigue}

The studies were varied in the type of fatigue that was examined. An increase in research activity about fatigue and its dimensions is evident because $65 \%$ of the 23 studies were published from 2017 to 2019. Cognitive fatigue has been consistently included in the literature as a dimension and a factor of discussion in 20 of the 23 studies from this review. The remaining three studies focused on general fatigue, motor or physical fatigue, and cognitive performance.

\section{Study Designs}

The predominant research design used consisted of cohort studies $(n=11)$ using convenience samples from MS centers or clinics. Fatigue was measured through a variety of self-reporting questionnaires and the most frequently used was the Modified Fatigue Impact Scale because it offered a multidimensional assessment (Braley \& Chervin, 2010; Colbeck, 2018; Golan et al., 2018; Gullo et al., 2019; Morrison \& Stuifbergen, 2016; Vucic et al., 2010). There were three studies that compared scores on self-reporting questionnaires with MRI scans (Sander et al., 2016; Touzet, 2017; Wilting et al., 2016). One cohort study tested participants fatigue using a wearable device called an accelerometer and the data were downloaded and analyzed by a specific software (Blikman et al., 2018). Another study utilized a naming exercise, Block Cyclic Naming Task, in researching MS cognitive fatigue (Cehelyk et al., 2019). Two studies were systematic reviews (Hanken et al., 2015; Walker et al., 2019). Three studies were longitudinal, ranging from three to six years (Berard et al., 2018; Damasceno et al., 2019; Golan et al., 2018).

\section{Outcomes}

The research studies discussed causes of cognitive fatigue resulting from central nervous system dysfunction, damage from the disease process, abnormal hormone levels, and immunological functioning with associated conditions such as sleep disorders, depression and difficulties with sensory processing (Braley \& Chevin, 2010; Colbeck, 2018; Hinz et al., 2018; Jason et al., 2010; Rooney et al., 2019; Vucic et al., 2010). Hinz et al. (2018) strongly recommended that gender should be included in developing and analyzing scales that evaluate fatigue. Moreover, these researchers reported that female patients reported more incidence of fatigue than males in all three dimensions: physical, emotional and cognitive. Wilting et al. (2016) concluded from MRI scans and morphologic analyses among patients with a recent diagnosis of RRMS and cognitive fatigue showed changes in the thalamic region of their brains compared to similar patients who did not exhibit cognitive fatigue. Aldughmi et al. (2017) used instruments that evaluated activities of daily living and how associated tasks were causing fatigue to participants with MS. This illustrates how much a person with MS is struggling on a daily basis with ordinary, usual functions. Other researchers (Yalachkov et al., 2019) found no significant effect on cognitive or motor fatigue in the quality of life of patients with RRMS and primary and secondary progressive MS.

In their longitudinal study, Berard et al. (2018) found that early in the diagnosis of MS, patients are vulnerable to cognitive fatigue. However, patients seen in the clinic setting are often assessed only for physical task performance or motor fatigue. The researchers concluded that cognitive effort should also be assessed in the clinic setting. Both cognitive and physical fatigue should be considered as separate domains during assessments (Berard et al., 2018).

Sander et al. (2016) divided MS participants (RRMS and Secondary Progressive) - those with fatigue and those without, and tested them using the Fatigue Scale for Motor and Cognition and had MRI scans. An analysis was performed to determine the relevance of the participants' cognitive fatigue status in relation to the number of MS relapses over 17 months and the MRI results. The researchers concluded that patients with cognitive fatigue developed increased brain atrophy and MS relapses than those without cognitive fatigue, suggesting an aggressive inflammation not typically seen in patients with MS (Sander et al., 2016).

\section{Discussion}

The most important finding related to this integrative review was related to the most prevalent type of MS, the RRMS type, where there are recurring relapses with the increased risk of progression to a more severe form (Halper \& Harris, 2017). RRMS patients need to adhere to their medication regimen to prevent this progression. A possible explanation for questionable medication adherence is the physical and cognitive struggle of MS patients to function while suffering from fatigue that medication adherence may not be possible (Aldughmi et al. 2017).

At the time of diagnosis, sixty percent of MS patients are employed and the highest incidence of MS onset is between the ages of 20 and 40 years of age (Halper \& Harris, 2017). These are adults in the prime of their lives and it is imperative to have the resources and research data regarding extra social benefits necessary to assist them to function optimally.

The weakness of the research about fatigue and cognitive fatigue is that there is a lack of a clear conceptual framework for the study of fatigue in neurological conditions (Walker et al., 2019). One study out of 23 outlined a theoretical basis for the research (Colbeck, 2018). In addition, there is no unified and objective definition for cognitive fatigue (Berard, 2018).

Many of the research in this review were cohort and control studies and the sampling were purposeful or convenience in nature. Purposeful sampling is a type of non-probability sampling where participants are those who meet the needs of the study and they are not randomized (Shadish et al., 2002). Samples were 
recruited through a MS center or known MS clinic of a neurology department of a university affiliated facility. This sampling method affects external validity and generalization of results. Additionally, studies in this integrative review did not employ randomization of samples in experimental and control groups. According to Shadish et al. (2002) this affects the validity of the studies as random assignment supports internal validity.

Two important therapies that were not accounted for by the studies were complementary and alternative therapies such as meditation and relaxation techniques. MS care teams suggested to incorporate these into patients' lives, if at all indicated (Halper \& Harris, 2017). The inclusion of medical marijuana and other alternative therapies may have had confounding effects on the study outcomes related to fatigue but were not explored.

Future research could use a tested theoretical framework to guide the studies. This will give more support in the development of a universal definition for cognitive fatigue in MS. In addition, three studies used a controlled methodology but without random assignment for experimental and control groups. Perhaps more randomized control methodologies could be employed to support validity of the studies.

\section{Conclusion}

Cognitive fatigue and MS are areas where more research is needed. The outcomes of the studies were encouraging in understanding cognitive fatigue, possible underlying causes, specific testing especially early in the diagnosis of MS, and the effects of specific types of fatigue that will influence clinical care. The research in cognitive fatigue has grown significantly in the last three to four years. More research is necessary in order to help patients with this dimension of MS fatigue.

Acknowledgement: The author acknowledges the assistance extended by the university's professional medical librarian, Ms. Amy Lyons, EMBA, MLS, for the scientific literature search.

Table 3

Description of Extracted Study Data

\begin{tabular}{|c|c|c|c|c|c|c|}
\hline $\begin{array}{l}\text { First Author/ } \\
\text { Year/Country }\end{array}$ & Theme & Type of Fatigue & Type of MS & $\begin{array}{c}\text { Participants } \\
\text { Number/Ages }\end{array}$ & $\begin{array}{c}\text { Study Design } \\
\text { Theory } \\
\text { Framework }\end{array}$ & Outcomes \\
\hline $\begin{array}{l}\text { Aldughmi/2017/ } \\
\text { USA }\end{array}$ & $\begin{array}{l}\text { Fatigability } \\
\& \text { Perceived } \\
\text { Fatigue } \\
\text { Manifestation }\end{array}$ & $\begin{array}{l}\text { Physical or } \\
\text { cognitive }\end{array}$ & $\begin{array}{l}\text { RRMS or } \\
\text { secondary } \\
\text { progressive }\end{array}$ & $\begin{array}{l}\mathrm{N}=52 \\
\text { Mean age } 47 \\
\text { (SD } 10 \text { yrs.) }\end{array}$ & $\begin{array}{l}\text { Cohort study } \\
\text { No theoretical } \\
\text { framework }\end{array}$ & $\begin{array}{l}\text { Increased } \\
\text { perceived fatigue } \\
\text { is not always } \\
\text { associated with } \\
\text { decrease in } \\
\text { performance }\end{array}$ \\
\hline $\begin{array}{l}\text { Berard/2018/ } \\
\text { Canada }\end{array}$ & $\begin{array}{l}\text { Cognitive } \\
\text { impairment } \\
\text { Manifestation }\end{array}$ & Cognitive & RRMS & $\begin{array}{l}\mathrm{N}=64 \\
32 \text { tested } \\
32 \text { control } \\
18-65 \text { yrs. }\end{array}$ & $\begin{array}{l}\text { Longitudinal } \\
\text { 3yr Case Cntrl } \\
\text { No theoretical } \\
\text { framework }\end{array}$ & $\begin{array}{l}\text { Cognitive } \\
\text { fatigue may be a } \\
\text { sensitive maker } \\
\text { of cognitive } \\
\text { impairments }\end{array}$ \\
\hline $\begin{array}{l}\text { Blikman/2018/ } \\
\text { Netherlands }\end{array}$ & $\begin{array}{l}\text { Dimensions } \\
\text { of fatigue } \\
\text { Manifestation }\end{array}$ & $\begin{array}{l}\text { subjective, } \\
\text { physical, } \\
\text { cognitive, } \\
\text { psychological }\end{array}$ & $\begin{array}{l}\text { RRMS, primary } \\
\text { and secondary } \\
\text { progressive, }\end{array}$ & $\begin{array}{l}\mathrm{N}=212 \\
\text { Ages } 18-70 \mathrm{yrs} . \\
\text { Mean 48yrs. }\end{array}$ & $\begin{array}{l}\text { Cohort study } \\
\text { No theoretical } \\
\text { framework }\end{array}$ & $\begin{array}{l}\text { Physical } \\
\text { behavior is not } \\
\text { associated with } \\
\text { other dimensions } \\
\text { of fatigue }\end{array}$ \\
\hline $\begin{array}{l}\text { Braley/2010/ } \\
\text { USA }\end{array}$ & $\begin{array}{l}\text { Fatigue: multi- } \\
\text { factorial Cause }\end{array}$ & $\begin{array}{l}\text { Physical, } \\
\text { cognitive, } \\
\text { chronic }\end{array}$ & $\begin{array}{l}\text { All types/ } \\
\text { subtypes }\end{array}$ & $\begin{array}{l}\text { No specific } \\
\text { sample }\end{array}$ & $\begin{array}{l}\text { Descriptive } \\
\text { review of rating } \\
\text { instruments } \\
\text { No theoretical } \\
\text { framework }\end{array}$ & $\begin{array}{l}\text { Identify treatable } \\
\text { causes to have } \\
\text { a positive effect } \\
\text { in the lives of } \\
\text { PwMS }\end{array}$ \\
\hline $\begin{array}{l}\text { Cehelyk/2019/ } \\
\text { USA }\end{array}$ & $\begin{array}{l}\text { Fatigue and } \\
\text { fatigability } \\
\text { Evaluation }\end{array}$ & $\begin{array}{l}\text { Physical, } \\
\text { cognitive, } \\
\text { objective, } \\
\text { subjective }\end{array}$ & $\begin{array}{l}\text { All MS types/ } \\
\text { subtypes and all } \\
\text { disabilities }\end{array}$ & $\begin{array}{l}\mathrm{N}=20 \\
\text { Ages }>18 \text { yrs. } \\
\text { Mean } 43 \text { yrs. } \\
\text { (SD } 10 \text { yrs) }\end{array}$ & $\begin{array}{l}\text { Cohort study No } \\
\text { theory }\end{array}$ & $\begin{array}{l}\text { Association } \\
\text { between } \\
\text { subjective } \\
\text { and objective } \\
\text { cognitive fatigue } \\
\text { in patients with } \\
\text { MS }\end{array}$ \\
\hline
\end{tabular}




\begin{tabular}{|c|c|c|c|c|c|c|}
\hline $\begin{array}{l}\text { Claros- } \\
\text { Salinas/2012/ } \\
\text { German }\end{array}$ & $\begin{array}{l}\text { Induced } \\
\text { cognitive } \\
\text { fatigue } \\
\text { Manifestation }\end{array}$ & Cognitive & $\begin{array}{l}\text { All types/ } \\
\text { subtypes with } \\
\text { cognitive fatigue }\end{array}$ & $\begin{array}{l}\mathrm{N}=32 \mathrm{w} / \\
\mathrm{MS} \text { and } \mathrm{N}=20 \\
\text { healthy controls } \\
\text { Mean age } 47 \mathrm{yrs} \text {. } \\
\text { (SD } 9 \text { yrs.) }\end{array}$ & $\begin{array}{l}\text { Control trial } \\
\text { w/o random No } \\
\text { theory }\end{array}$ & $\begin{array}{l}\text { Cognitive } \\
\text { load induces } \\
\text { cognitive fatigue }\end{array}$ \\
\hline $\begin{array}{l}\text { Colbeck/2018/ } \\
\text { Canada }\end{array}$ & $\begin{array}{l}\text { Sensory over } \\
\text { responsiveness } \\
\text { Cause }\end{array}$ & Cognitive & $\begin{array}{l}\text { All MS types / } \\
\text { subtypes }\end{array}$ & $\begin{array}{l}\mathrm{N}=30 \\
\text { Ages }>18 \text { years }\end{array}$ & $\begin{array}{l}\text { Cohort study } \\
\text { Theory } \\
\text { Dunn's Model } \\
\text { of Sensory } \\
\text { Processing }\end{array}$ & $\begin{array}{l}\text { Sensory } \\
\text { processing } \\
\text { preferences } \\
\text { helps influence } \\
\text { cognitive fatigue }\end{array}$ \\
\hline $\begin{array}{l}\text { Damasceno/2019 } \\
\text { /Brazil }\end{array}$ & $\begin{array}{l}\text { Cognitive } \\
\text { impairment } \\
\text { Manifestation }\end{array}$ & Cognitive & RRMS & $\begin{array}{l}\mathrm{N}=42 \mathrm{w} / \mathrm{RRMS} \\
30 \text { healthy } \\
\text { control Ages } 31 \\
\text { (SD } 7 \text { years) }\end{array}$ & $\begin{array}{l}\text { Longitudinal } \\
\text { Control w/o } \\
\text { random 6yrs No } \\
\text { theory }\end{array}$ & $\begin{array}{l}\text { Cognitive } \\
\text { impairment at } \\
\text { baseline was the } \\
\text { best predictor } \\
\text { of both physical } \\
\text { and cognitive } \\
\text { deterioration }\end{array}$ \\
\hline $\begin{array}{l}\text { Golan/2018/ } \\
\text { USA }\end{array}$ & $\begin{array}{l}\text { Impact fatigue } \\
\text { on cognitive } \\
\text { function } \\
\text { Manifestation }\end{array}$ & Cognitive & $\begin{array}{l}\text { RRMS, } \\
\text { Secondary } \\
\text { and Primary } \\
\text { Progressive }\end{array}$ & $\begin{array}{l}\mathrm{N}=699 \\
46 \text { yrs. (SD } \\
10.5 \mathrm{yrs} .)\end{array}$ & $\begin{array}{l}\text { Longitudinal } \\
\text { Cohort study } 6 \\
\text { yrs No theory }\end{array}$ & $\begin{array}{l}\text { Do not attribute } \\
\text { cognitive } \\
\text { impairment to } \\
\text { fatigue or mild } \\
\text { depression in } \\
\text { PwMS }\end{array}$ \\
\hline $\begin{array}{l}\text { Gullo/2019/ } \\
\text { Australia }\end{array}$ & $\begin{array}{l}\text { Daily function } \\
\text { Manifestation }\end{array}$ & $\begin{array}{l}\text { Cognitive and } \\
\text { physical fatigue }\end{array}$ & $\begin{array}{l}\text { All MS types / } \\
\text { subtypes }\end{array}$ & $\begin{array}{l}\mathrm{N}=74 \\
18-80 \text { yrs. Mean } \\
\text { age } 53 \text { yrs }\end{array}$ & $\begin{array}{l}\text { Cohort study No } \\
\text { theory }\end{array}$ & $\begin{array}{l}\text { Cognitive } \\
\text { and physical } \\
\text { fatigue should } \\
\text { be considered } \\
\text { distinct domains }\end{array}$ \\
\hline $\begin{array}{l}\text { Hanken/2015/ } \\
\text { German }\end{array}$ & $\begin{array}{l}\text { Neuronal } \\
\text { networks } \\
\text { Evaluate }\end{array}$ & $\begin{array}{l}\text { Fatigue and } \\
\text { cognitive } \\
\text { performance }\end{array}$ & $\begin{array}{l}\text { All MS types / } \\
\text { subtypes }\end{array}$ & $\begin{array}{l}\text { No specific } \\
\text { sample }\end{array}$ & $\begin{array}{l}\text { Systematic } \\
\text { review of } \\
\text { descriptive } \\
\text { studies }\end{array}$ & $\begin{array}{l}\text { Include alerting } \\
\text { /vigilance } \\
\text { testing into } \\
\text { clinical routine } \\
\text { evaluation of } \\
\text { MS patients } \\
\text { experiencing } \\
\text { fatigue }\end{array}$ \\
\hline $\begin{array}{l}\text { Harrison/2017/ } \\
\text { British }\end{array}$ & $\begin{array}{l}\text { Cognitive } \\
\text { fatigability } \\
\text { Evaluate }\end{array}$ & Cognitive & $\begin{array}{l}\text { All MS types/ } \\
\text { subtypes }\end{array}$ & $\begin{array}{l}\text { No specific } \\
\text { sample }\end{array}$ & $\begin{array}{l}\text { Descriptive } \\
\text { study No theory }\end{array}$ & $\begin{array}{l}\text { Self-report } \\
\text { instruments } \\
\text { are a valid } \\
\text { way to assess } \\
\text { perception of } \\
\text { fatigue and its' } \\
\text { impact }\end{array}$ \\
\hline $\begin{array}{l}\text { Hinz/2018/ } \\
\text { German }\end{array}$ & $\begin{array}{l}\text { Fatigue } \\
\text { Questionnaires } \\
\text { Evaluate }\end{array}$ & $\begin{array}{l}\text { Physical, } \\
\text { emotional, and } \\
\text { cognitive }\end{array}$ & $\begin{array}{l}\text { Unknown } \\
\text { General German } \\
\text { Population }\end{array}$ & $\begin{array}{l}\mathrm{N}=2411 \\
\text { Male }=1121 \\
\text { Mean } 49 \text { yrs. } \\
\text { Female = } 1290 \\
\text { Mean } 50 \text { yrs. }\end{array}$ & $\begin{array}{l}\text { Cohort study No } \\
\text { theory }\end{array}$ & $\begin{array}{l}\text { Consider gender } \\
\text { when accounting } \\
\text { for the amount } \\
\text { and type of } \\
\text { fatigue }\end{array}$ \\
\hline Jason/2010/USA & $\begin{array}{l}\text { Pathological } \\
\text { and non- } \\
\text { pathological } \\
\text { Cause }\end{array}$ & $\begin{array}{l}\text { Cognitive or } \\
\text { physical }\end{array}$ & $\begin{array}{l}\text { All MS types/ } \\
\text { subtypes }\end{array}$ & No sample & $\begin{array}{l}\text { Descriptive } \\
\text { studies No } \\
\text { theory }\end{array}$ & $\begin{array}{l}\text { Lack of specific, } \\
\text { comprehensive } \\
\text { definition of } \\
\text { fatigue }\end{array}$ \\
\hline
\end{tabular}




\begin{tabular}{|c|c|c|c|c|c|c|}
\hline $\begin{array}{l}\text { Morrison/2016/ } \\
\text { USA }\end{array}$ & $\begin{array}{l}\text { Predictors } \\
\text { Manifestation }\end{array}$ & $\begin{array}{l}\text { Physical, } \\
\text { cognitive, } \\
\text { psychosocial }\end{array}$ & $\begin{array}{l}\text { All MS types/ } \\
\text { Subtypes long- } \\
\text { standing mean } \\
26.5 y r s\end{array}$ & $\begin{array}{l}\mathrm{N}=331 \\
35 \text { to } 89 \text { years } \\
\text { mean } 63 \text { yrs. } \\
\text { (SD 9yrs) }\end{array}$ & $\begin{array}{l}\text { Cohort study No } \\
\text { theory }\end{array}$ & $\begin{array}{l}\text { Depressive sx's } \\
\text { was the strongest } \\
\text { predictor of total } \\
\text { and cognitive } \\
\text { fatigue impact }\end{array}$ \\
\hline $\begin{array}{l}\text { Rooney/2019/ } \\
\text { Scotland }\end{array}$ & $\begin{array}{l}\text { Prevalence } \\
\text { Cause }\end{array}$ & $\begin{array}{l}\text { Physical, } \\
\text { cognitive and } \\
\text { psychological }\end{array}$ & $\begin{array}{l}\text { Progressive and } \\
\text { non-progressive }\end{array}$ & $\begin{array}{l}\mathrm{N}=412 \\
\text { Mean } 46 \text { yrs. } \\
\text { SD 11.5yrs }\end{array}$ & $\begin{array}{l}\text { Cohort study } \\
\text { No theory }\end{array}$ & $\begin{array}{l}\text { Fatigue more } \\
\text { prevalent with } \\
\text { progressive } \\
\text { types of MS }\end{array}$ \\
\hline $\begin{array}{l}\text { Sander/2016/ } \\
\text { Switzerland }\end{array}$ & $\begin{array}{l}\text { Disease } \\
\text { Progression } \\
\text { Manifestation }\end{array}$ & Cognitive & $\begin{array}{l}\text { RRMS and } \\
\text { Secondary } \\
\text { Progressive }\end{array}$ & $\begin{array}{l}\mathrm{N}=46 \\
\text { MS pts and } 14 \\
\text { healthy control. } \\
\text { Ages } 18-46 \text { yrs. }\end{array}$ & $\begin{array}{l}\text { Control without } \\
\text { randomization } \\
\text { No theory }\end{array}$ & $\begin{array}{l}\text { More relapses } \\
\text { with cognitive } \\
\text { fatigue }\end{array}$ \\
\hline $\begin{array}{l}\text { Touzet/2017/ } \\
\text { France }\end{array}$ & $\begin{array}{l}\text { Cortical } \\
\text { inhibition } \\
\text { Cause }\end{array}$ & Cognitive & $\begin{array}{l}\text { All MS types/ } \\
\text { Subtypes }\end{array}$ & No sample & $\begin{array}{l}\text { Descriptive } \\
\text { study No theory }\end{array}$ & $\begin{array}{l}\text { Efficient } \\
\text { NonREM sleep } \\
\text { may be therapy } \\
\text { against cognitive } \\
\text { fatigue }\end{array}$ \\
\hline $\begin{array}{l}\text { Vaughn/2018/ } \\
\text { USA }\end{array}$ & $\begin{array}{l}\text { Fatigue at } \\
\text { baseline } \\
\text { manifestation }\end{array}$ & Fatigue & $\begin{array}{l}\text { RRMS, } \\
\text { Progressive MS }\end{array}$ & $\begin{array}{l}\mathrm{N}=2714 \text { Mean } \\
\text { age } 45 \mathrm{yrs} .\end{array}$ & $\begin{array}{l}\text { Cohort } \\
\text { retrospective } \\
\text { study No theory }\end{array}$ & $\begin{array}{l}\text { Base line fatigue } \\
\text { is associated } \\
\text { with worsening } \\
\text { disability }\end{array}$ \\
\hline $\begin{array}{l}\text { Vucic/2010/ } \\
\text { Australia }\end{array}$ & $\begin{array}{l}\text { Fatigue } \\
\text { mechanisms } \\
\text { cause }\end{array}$ & $\begin{array}{l}\text { Motor sign } \\
\text { fatigue }\end{array}$ & $\begin{array}{l}\text { All MS types/ } \\
\text { Subtypes }\end{array}$ & No sample & $\begin{array}{l}\text { Descriptive } \\
\text { study Author's } \\
\text { own theory }\end{array}$ & $\begin{array}{l}\text { Current evidence } \\
\text { for fatigue in } \\
\text { MS implies grey } \\
\text { and white matter } \\
\text { dysfunction \& } \\
\text { atrophy }\end{array}$ \\
\hline $\begin{array}{l}\text { Walker/2019/ } \\
\text { Canada }\end{array}$ & $\begin{array}{l}\text { Fatigability } \\
\text { evaluation }\end{array}$ & Cognitive & $\begin{array}{l}\text { All MS types/ } \\
\text { Subtypes }\end{array}$ & No sample & $\begin{array}{l}\text { Systematic } \\
\text { Review No } \\
\text { theory }\end{array}$ & $\begin{array}{l}\text { Study of fatigue } \\
\text { in neurological } \\
\text { conditions lacks } \\
\text { clear conceptual } \\
\text { framework }\end{array}$ \\
\hline $\begin{array}{l}\text { Wilting/2016/ } \\
\text { German }\end{array}$ & $\begin{array}{l}\text { Provoking } \\
\text { fatigue } \\
\text { Evaluation }\end{array}$ & cognitive & $\begin{array}{l}\text { RRMS, Primary } \\
\text { progressive, } \\
\text { secondary } \\
\text { progressive }\end{array}$ & $\begin{array}{l}\mathrm{N}=32 \text { Age } 29- \\
64 \text { Mean } 47 \text { yrs. } \\
\text { SD } 9 \text { yrs. } \mathrm{N}=20 \\
\text { healthy controls }\end{array}$ & $\begin{array}{l}\text { Control trial } \\
\text { without } \\
\text { Randomization } \\
\text { No theory }\end{array}$ & $\begin{array}{l}\text { Cognitive } \\
\text { fatigue can } \\
\text { be measured } \\
\text { and assessed } \\
\text { objectively }\end{array}$ \\
\hline $\begin{array}{l}\text { Yalachkov/2019 } \\
\text { German }\end{array}$ & $\begin{array}{l}\text { Quality of Life } \\
\text { Manifestation }\end{array}$ & $\begin{array}{l}\text { General fatigue, } \\
\text { cognitive } \\
\text { impairment }\end{array}$ & $\begin{array}{l}\text { RRMS and } \\
\text { Progressive } \\
\text { (primary and } \\
\text { secondary) }\end{array}$ & $\begin{array}{l}\mathrm{N}=55 \text { Mean } \\
\text { Age RRMS } 38 \\
\text { SD } 11 \text { yrs. Mean } \\
\text { Age Progressive } \\
55 \text { SD } 11 \text { yrs. }\end{array}$ & $\begin{array}{l}\text { Cohort study No } \\
\text { theory }\end{array}$ & $\begin{array}{l}\text { There was no } \\
\text { significant effect } \\
\text { of cognitive or } \\
\text { motor fatigue in } \\
\text { quality of life }\end{array}$ \\
\hline
\end{tabular}




\section{References}

Aldughmi, M., Bruce, J., \& Siengsukon, C.F. (2017). Relationship between fatigability and perceived fatigue measured using the neurological fatigue index in people with multiple sclerosis. International Journal of MS Care,19, 232-239. https://dx.doi.org/10.7224/1537-2073.2016-059

Berard, J. A., Smith, A. M., \& Walker, L. A. S. (2018). A longitudinal evaluation of cognitive fatigue on a task of sustained attention in early relapsing-remitting multiple sclerosis. Journal of MS Care, 20, 55-61. https://dx.doi. org/10.7224/1537-2073.2016-106

Blikman, L. J. M., Van Meeteren, J., Rizopoulos, D., De Groot, V., Beckerman, H., Stam, H. J., \& Bussmann, J. B. J. (2018). Physical behavior is weakly associated with physical fatigue in persons with multiple sclerosis-related fatigue. Journal of Rehabilitation Medicine, 50, 821- 827. https://dx.doi. org/10.2340/16501977-2375

Braley, T. J., \& Chervin, R. D. (2010). Fatigue in multiple sclerosis: Mechanisms, evaluation and treatment. SLEEP, 33(8), 1061-1067. https://dx.doi.org/10.1093/ sleep/33.8.1061

Cehelyk, E.K., Harvey, D.Y., Grubb, M.L., Jalel, R., El-Sibai, M.S., Markowitz, C.E., Berger, J.R., Hamilton, R.H., \& Chahin, S. (2019). Uncovering the association between fatigue and fatigability in multiple sclerosis using cognitive control. Multiple Sclerosis and Related Disorders, 27, 269275. https://dx.doi.org/10.1016/j.msard.2018.10.112

Charmaz, K. (2012). Constructing grounded theory: A practical guide through qualitative analysis. Sage.

Claros-Salinas, D., Dittmer, N., Neumann, M., Sehle, A., Spiteri, S., Willmes, K., Schoenfeld, M.A., \& Dettmers, C. (2013). Induction of cognitive fatigue in MS patients through cognitive and physical load. Neuropsychological Rehabilitation: An International Journal, 23(2), 182-201. https://dx.doi.org/10.1080/09602011.2012.726925

Colbeck, M. (2018). Sensory processing, cognitive fatigue, and quality of life in multiple sclerosis. Canadian Journal of Occupational Therapy, 85(2), 169-175. https://dx.doi. org/10.1177/0008417417727298

Damasceno, A., Pimentel-Silva, L. R., Damasceno, B. P., \& Cendes, F. (2019). Cognitive trajectories in relapsingremitting multiple sclerosis: A longitudinal 6-year study. Multiple Sclerosis Journal, 1-12. https://dx.doi. org/10.1177/1352458519878685

Given, B. \& Sherwood, P. (2006). Fatigue. In B.J. Ackley \& G.B. Ladwig (Eds.), Nursing diagnosis handbook a guide to planning care (7th ed.). Mosby Elsevier.

Golan, D., Doniger, G.M.,Wissemann, K., Zarif, M., Bumstead, B., Buhse, M., Fafard, L., Lavi, I., Wilken, J., \& Gudesblatt, M. (2018). The impact of subjective cognitive fatigue and depression on cognitive function in patients with multiple sclerosis. Multiple Sclerosis Journal, 24(2), 196-204. https://dx.doi.org/10.1177/1352458517695470
Gullo, H.L., Fleming, J., Bennett, S., \& Shum, D.H.K. (2019). Cognitive and physical fatigue are associated with distinct problems in daily functioning, role fulfilment, and quality of life in multiple sclerosis. Multiple Sclerosis and Related Disorders, 31, 118-123. https://dx.doi.org/10.1016/j. msard.2019.03.024

Halper, J. \& Harris, C. (2017). Nursing practice in multiple sclerosis a core curriculum (4th ed.). Springer Publishing Company.

Hanken, K., Eling, P., \& Hildebrandt, H. (2015). Is there a cognitive signature for MS-related fatigue? Multiple Sclerosis Journal, 21(4), 376-381. https://dx.doi. org/10.1177/1352458514549567

Harrison, A.M., das Nair, R., \& Moss-Morris, R. (2017). Operationalising cognitive fatigability in multiple sclerosis: A Gordian knot that can be cut? Multiple Sclerosis Journal, 23(13), 1682-1696. https://dx.doi. org/10.1177/1352458516681862

Hinz, A., Weis, J., Brähler, E., \& Mehnert, A. (2018). Fatigue in the general population: German normative values of the EORTC QLQ-FA12. Quality of Life Research, 27, 26812689. https://dx.doi.org/10.1007/s11136-018-1918-0

Jason, L.A., Evans, M., Brown, M., \& Porter, N. (2010). What is fatigue? Pathological and non-pathological fatigue. Physical Medicine and Rehabilitation, 2, 327-331. https:// dx.doi.org/10.1016/j.pmrj.2010.03.028

Marshall, R.S. \& Mayer, S.A. (2007). Demyelinating and inflammatory disorders of the central nervous system. On Call Neurology (3rd ed.). Saunders Elsevier.

Mazurek Melnyk, B., Fineout-Overholt, E., Stillwell, S.B., \& Williamson, K.M. (2010). Evidence-based practice step by step: The seven steps of evidence-based practice. American Journal of Nursing, 110(1), 51-53. https://dx.doi. org/10.1097/01.NAJ.0000366056.06605.d2

Moher, D., Liberati, A., Tetzlaff, J., \& Altman, D.G., \& The Prisma Group. (2009). Preferred reporting items for systematic review and meta-analyses: The PRISMA statement. BMJ, 339, b2535. https://dx.doi.org/10.1136/ bmj.b2535

Moher, D., Shamseer, L., Clarke, M., Ghersi, D., Liberati, A., Petticrew, M., Shekelle, P., Stewart, L. A., \& The Prisma-P Group. (2015). Preferred reporting items for systematic review and meta-analysis protocols (PRISMA-P) 2015 statement. Systematic Reviews, 4(1), 1-9. https://dx.doi. org/10.1186/2046-4053-4-1

Morrison, J.D. \& Stuifbergen, A.K. (2016). Predictors of fatigue impact in persons with long-standing multiple sclerosis. Journal of Neuroscience Nursing, 48(3): 143-150. https://dx.doi.org/10.1097/JNN.0000000000000208

Rooney, S., Wood, L., Moffat, F., \& Paul, L. (2019). Prevalence of fatigue and its association with clinical features in progressive and non-progressive forms of multiple sclerosis. Multiple Sclerosis and Related Disorders, 28, 276-282. https://dx.doi.org/10.1016./j.msard.2019.01.011 